\title{
Theodicy and Social Attitudes Towards Punishment
}

\author{
Fidinda Avitasari ${ }^{*}$, Fathul Lubabin Nuqul ${ }^{2}$ \\ ${ }^{1}$ Universitas Islam Negeri Maulana Malik Ibrahim Malang, Indonesia \\ ${ }^{2}$ Universitas Islam Negeri Maulana Malik Ibrahim Malang, Indonesia \\ *Corresponding author. Email: fidindaavitasari@gmail.com
}

\begin{abstract}
The increasing number of crimes inspires people to give punishment to the perpetrators. Religious values influence this punishment. Theodicy is a study that studies the existence of an all-just God. From the perspective of Islamic theology, there are two points of view on his evil actions; firstly, the Mu'tazilah group considers that humans are total free will for their actions, while the Ahlussunnah wal jama'ah group considers that God has a destiny in human life and humans have the opportunity to determine their behaviour. The result reveal that needs human efforts to maintain social order by law enforcement and learning.
\end{abstract}

\section{Keywords: Theodicy, Crime, Punishment}

\section{INTRODUCTION}

Crime and violence often occur in people who behave religiously. Call it Indonesia; based on data from the Indonesian National Police, the crime rate that occurred compared to the previous year showed an increase in the number in the 24th week of 2020 . In the $23 \mathrm{rd}$ week, there were 4,244 criminal cases. In the 24 th week, it increased again by 5,876 cases [1]. According to police data, cases that have experienced an increase are gambling, theft by weight, vehicle theft, embezzlement, and narcotics abuse. The highest increase in cases occurred in the 23rd week with gambling cases, which were 52 cases. Then in the 24th week, it doubled to 104 cases. Cases of theft of twowheeled vehicles increased by $98.25 \%$, from 114 cases previously, increasing to 226 cases in the following week. In serious theft cases, there was $68.61 \%$ or 411 cases in the 23 rd week and increased to 693 cases the following week. In the case of embezzlement, the increase occurred around $42.71 \%$, with 421 cases in the 24th week. Then in the case of narcotics abuse, there were 649 cases.

Increased crime motivates others to punish. There are many grounds for the desire to punish. Some reactions to crime are based on a sense of justice and moral enforcement. Justice in punishment leads to retributive or motive to retaliate. Another view is restoration. This view refers to efforts to correct the perpetrators of the crime. In the Muslim community, attitudes towards crime are based on religious beliefs. Belief, ritual, and practice have placed God and his word at the centre of human life. syariah is a set of teachings containing religious and moral concepts covering all aspects of human life. The Islamic penal system is a moral system that has many influences on the individual level and the social consciousness of Muslims. Syariah has the effect of preventing crime and has contributed to the low level of crime in Islamic society [2].

The reason that Syariah and Islamic criminal law impact reducing crime is by several sources of empirical research. In several studies on the attitudes of Muslims to the seriousness of deviant behavior in various countries (India, Indonesia, Italy, Iran, Yugoslavia, and the United States) conducted by Newman (1976) [3], this study asked about nine actions that are considered deviant behavior in some cultures, including robbery, Incest, embezzlement, homosexuality, abortion, drug abuse, pollution creation, demonstrations and not helping people in danger. Among some of the questions that Newman asked respondents were "do you think these actions are prohibited by law?" the average answers that respond positively to the question in each country are as follows; Indonesia, 89.6; Iran, 87.6; Italy, 84.7; Yugoslavia, 77.0; India, 72.7; and the USA, 58.1 [3]. A positive answer to this question indicates the degree of social intolerance to crime. The results show that the opinion of the people of Indonesia and Iran, which are countries with a majority Muslim population towards crime, is more rigid (intolerant) than the nonIslamic community. A positive answer to this question indicates the degree of social intolerance to crime. The results show that the opinion of the people of Indonesia and Iran, which are countries with a 
majority Muslim population towards crime, is more rigid (intolerant) than the non-Islamic community. A positive answer to this question indicates the degree of social intolerance to crime. The results show that the opinion of the people of Indonesia and Iran, which are countries with a majority Muslim population towards crime, is more rigid (intolerant) than the non-Islamic community.

The stories of people in Al-Qur'an are expected to provide lessons for the readers to maintain every behavior. On the other hand, God is a just being and has power over his creatures. This belief in the Almighty God has two sides. First, it will mean that God, both good and bad, controls all human behavior. On the other hand, God does not want damage (crime) and will punish those who commit crimes. This paper aims to discuss human behavior, linked to belief in God's will on human behavior. In theological studies, the concept of God's justice is known as theodicy studies.

\section{DEFINION OF THEODICY}

Theodicy is etymologically derived from the Greek words "theos", which means God and "dike", which means justice. This theological study refers to justifying God for his omnibenevolence. In the Dictionary of Philosophy, Lorens put the meaning of theodicy into three perspectives. First, theodicy is a science that tries to justify God's way in human life. Second, theodicy is an effort to maintain the goodness and justice of God when evil, whether moral or natural, occurs and causes suffering to humans. Third, theodicy is an attempt to link the relationship between the existence of evil with the greatness and mercy of God [4].. Based on the three definitions above, it can be concluded that theodicy is an effort to defend and defend the existence of God related to His justice and greatness to the reality that occurs in human life [5].

\section{THEODICY AND THE PROBLEM OF CRIME ACCORDING TO WESTERN LEADERS}

The discussion of theodicy refers to the manifestation of God raised from existentialism. It means that the discussion of theodicy is more focused on the extent to which the mind can capture the existence of a God based on the data of the godhead concrete. The issue of God's justice and its relation to evil in the world is still a logical problem that is not easy to analyze scientifically. For religious humans, God is Almighty, Most Merciful, Most, and so on. However, it cannot be denied that in this world, there are often problems of crime in human life, both the problem of moral crimes such as rape, murder, beheading, robbery, corruption, and others. Also, the problem of natural crimes such as the disasters that befell victims in Rohingya, Aceh, Nepal, Lombok and others. These crime cases seem to indicate a different contradiction to the nature of His greatness. This thought is called theodicy, initiated by the philosopher Epicurus from the Hellenistic era, which became the historical root of the debate about Theodicy in the West [6].

The problem of crime initiated by Epicurus then inspired the philosopher Gottfried Von Leibniz in 1710 in his writings entitled "Essais sur la Theodicee Bonte de Dieu, la Liberte de I'homme et I'origine du Mal", which if translated into Theodicy: Essays About the Goodness of God, the Freedom of Man and the Authenticity of Satan's nature [7]. The paper was made to show that the evil that occurs in the world is not against God's goodness, and this world is still in a good and beautiful condition [6]. Leibniz believed in the importance of theology in human life. Leibniz argues that crime is divided into three forms. The first is metaphysical evil. According to Harun Nasution, this type of crime is natural. Such as natural disasters, tsunamis, volcanic eruptions, earthquakes, etc [8].

Then the second is a physical crime, described as an outbreak such as the Covid 19 pandemic that makes humans suffer. This crime is intended to punish humans for protecting nature and the surrounding environment. The third is a moral crime, seen as a real crime committed by humans. This crime is a consequence of human freedom that crosses boundaries. God gave man the freedom to do whatever he wanted. Examples of these crimes are assault, robbery, kidnapping, and others [8]. Leibniz argues that the world now occupied by humans is the best place, and this opinion has similarities with alGhazali's idea that the world is the best place for humans [9]. Crimes that occur must have a good impact and benefit for humans. According to Leibniz, evil exists to realize the perfection of the world created by God [10].

The problem of evil is seen from beliefs about God and God's power. While theodicy is a relatively new discipline of philosophical study, the two have differences. The crime problem is the object of the problem, while theodicy is the response to the object of the problem (Latif, 2020) [10]. John Lennox shares his thoughts in a book called "Where is God in a Coronavirus World?" in which he touched on the issue of theodicy and how it responded. According to Lenox, humans have free will and can choose any path they want to take. This free will in psychology is closely related to Maslow's theory which states that every human being has free will to choose his path to become a human being who behaves well or badly. 
Lennox stated that human free will tends to choose evil deeds, which cause humans to receive punishment from God.

\section{THEODICY AND THE PROBLEM OF CRIME ACCORDING TO MUSLIM THINKERS}

Various Muslim philosophers, especially theologians, with their respective schools of thought, their orientation in discussing the problem is to maintain the monotheism and holiness of Allah. The emergence of philosophical thought is always based on the principle of monotheism. From an Islamic perspective, the crime problem has captured the attention of Muslim philosophers such as al-Kindi, Ibn Sina, al-Ghazali asy'ariyah, mu'tazillah, etc. Theologians with Mu'tazillah thoughts when looking at a crime that occurs in the world, such as natural disasters, are not seen from the manifestation of His will and actions but rather relate to the consequences of actions that have been carried out by humans or natural dynamics that are not in line with sunnatullah or the natural law. According to their beliefs, everything in the world has been created by God perfectly and in balance. All the evil that befalls humans in the world does not come from God. Bad deeds that arise are caused by imperfection, and Allah does not do bad because the only one who is perfect is Allah SWT. The concept of al-salah was al-salah is the teaching of their people who assert that the consequences of evil that occur in the universe do not come from God and all God's actions are for good. Thus, Mu'tazilillah theology views crime as an objective moral event. Bad deeds that arise are caused by imperfection, and Allah does not do bad because the only one who is perfect is Allah SWT. The concept of al-salah was al-salah is the teaching of their people who assert that the consequences of evil that occur in the universe do not come from God and all God's actions are for good. Thus, Mu'tazilllah theology views crime as an objective moral event. Bad deeds that arise are caused by imperfection, and Allah does not do bad because the only one who is perfect is Allah SWT. The concept of al-salah was al-salah is the teaching of their people who assert that the consequences of evil that occur in the universe do not come from God and all God's actions are for good. Thus, Mu'tazillah theology views crime as an objective moral event.

Meanwhile, Asyariah theology emphasizes a moderate view between God's creation and human freedom. According to the Syariah group, the view of God's justice can limit the power of God Almighty. However, God is not bound by the laws of His creation, and God acts justly in everything He does.
So, it can be interpreted that all the suffering that befalls humans is considered a form of God's justice desired for all of His creatures. Al-Asyariyah holds the concept of kasb or effort, which teaches that although God creates all actions, humans can choose the path of their actions. This freedom makes humans have responsibility for good deeds or bad deeds [11].

Meanwhile, the concept of theodicy conveyed by Al-Ghazali said that crime has to do with human personality. The source of human evil comes from human lust itself. Through his work in Ihya Ulumuddin in the chapter of the book, al-Tawhid wa al-Tawakkal states that nature is the perfect work of God. The creation of the universe has been designed according to God's will, and humans must believe that the universe is the best form that God created. AlGhazali's opinion about a perfectly created world gives readers confidence that this faith is one of the requirements for humans who want to reach the top ladder of the state of tawakkal and climb the ladder of spiritual perfection.

It was Al Ghazali's thoughts that later inspired Jalal al-Din al-Rumi. Human suffering by Rumi is not described as a theodicy problem that needs to be avoided but is seen as part of the experience of human spirituality. According to Rumi, trials and tests are media for self-purification that can free people from the busyness of worldly affairs. Humans whose purpose in life is only to fulfil animal desires will complain about God's justice. one should not be pessimistic in the face of suffering. According to Rumi, love for God is important in increasing spirituality. The attitude of patience, trust in the Lord, and having a taste of love in God is the key to achieving the perfection of spirituality himself. (Rouzati, 2013) [12].

Al-Ghazali and Rumi discussed the misery, disaster, and human suffering in theodicy. Humans who experience this suffering are humans who are being tested. Both views that the disasters and sufferings experienced are a form of trials and tests that aim to increase one's spiritual potential and find a way to God. Said Nursi was inspired by these two figures and responded close to Al-Ghazali and Rumi's views. Nursi juxtaposes the two opinions, where AlGhazali focuses on the aspect of God's omnipotence, while the basic view of Rumi departs from love [11]. So disasters and suffering are a form of trials and tests from God as evidence of God's love for His Servant, which must have wisdom behind it [13]

This opinion is in line with the theologians Ahl alSunnah wa al-Jamaah, who revealed that the universe is a new creation of God with the criteria of jism or body, far or reality, and 'arad or desire. These three 
elements cause a change in form from one form to another. For Asface theologians, the view that the universe was created from something that exists is not derived from the basic teachings of Islam. This thought is the Greek thought contained in the teachings of the Mu'tazillah theologians. This view contradicts the belief of the Ahl-Sunnah because this view views nature as qadim, which means doubling up on God or shirk. Theologian Asface also refuted the Atheists and Naturalists who claimed that nature formed by itself [14].

\section{OVERVIEW THE RELATION OF RELIGIOUS BELIEFS AND JUDGMENTS ON CRIME}

Moral, religion, and law are a unity in the order of Indonesian people's life that cannot be separated because there is a close relationship between these three things. For its adherents, religious teachings become a guide or guide in every aspect of their lives. All human behavior is equally regulated by law, religion, and morals. Likewise, a legal system that does not have the substance of justice and morality will eventually become barren. Therefore, the law separated from morality and justice cannot be called a law. Legal regulations are generally carried out voluntarily at the will of one's conscience because the law in its implementation has a role of moral support [15]. Sarwono states that religious factors influence behavior. Someone who has a high level of religiosity will behave according to the values of the religious teachings he adheres [16]. Daradjat expressed that religion fosters discipline. Someone in a dilemma will make various considerations of moral values that are understood in the teachings of his religion. Religious values that have been integrated with the mind guide one's behavior. Thus, a person's beliefs can manifest attitudes and behaviors according to their appreciation. [16].

Praise and reproach are the contents of morality, while the content of the law is orders and prohibitions with elements of coercion and threats to anyone who ignores them. The existence of elements of coercion and threats in the law is a must. If these elements are removed, then what happens is that the law becomes useless and meaningless. Therefore, between one society to another gives a different form. Each social order has certain ways that, if applied to force members of society to do something. Haziran states that law carried out without morals is an injustice, and morals without law that occur are everything that leads to animalistic behavior. There is a close relationship between social morality and the rule of law in society. The influence of social morality on legal orders that occur in society generally depends on the character of each community [17].

In Islam, the Qur'an and Hadith are used as a way of life for its adherents. Allah has set all the rules in the form of commands and prohibitions. It also contains a source of moral values which, when implemented, can cleanse the soul and at the same time distinguish humans from other animals. Morality is one of the goals carried out in enforcing worship to God. Like Muslims who perform Zakat worship to cleanse the soul, perform prayer services to avoid evil and vile deeds, perform fasting worship to refrain from the temptation of lust, and refrain from all bad deeds. Etc. Based on this information, it can be seen that its implementation [18].

God's justice is believed to guide his servants' behavior. This justice is manifest in the laws that apply in society. Obedience to the law will bring people certainty and justice in their behavior which ultimately makes a society peaceful. Ignoring the law will only lead to an irregular life. Legal habituation efforts are not only based on written laws but also on the teachings of behavior and example that must be carried out consistently for all people. Law enforcement is only part of the habituation of reminders that must be preceded by education about God's justice. Family, school, and community are the three domains of education responsible for teaching 'good' behavior to all members of society.

\section{CLOSING}

Religion wants good for all people who believe in it. The human task is to operationalize the concept of texts into a legal order to behave in a concrete and logical society without eliminating monotheism in God. The problems that arise in the operationalization order do not eliminate the glory of God as the almighty will.

\section{REFERENCES}

[1] D. Halim, (2020, Juni 16). Polri Sebut Angka Kriminalitas Naik 38,45 Persen dalam Sepekan. (B. Galih, Editor) Retrieved September 11, 2021, from nasional.kompas.com: https://nasional.kompas.com/read/2020/06/16/1 8151321/polri-sebut-angka-kriminalitas-naik3845-persen-dalam-sepekan

[2] S. H. Serajzadeh, "Islam and crime: The moral comunity of muslim". Journal of Arabic and Islamic Studies, (2002) 111-131. 
[3] G. R. Newman, 1976. Comparative Deviance: Perception and Law in Six Cultures. New York: Elsevier Scientific Pub. Co. — 1982. "Khomeini and Criminal Justice: Notes on Crime and Culture." The Journal of Criminal Law and Criminology 73 (2) (1982), pp.561-81.

[4] T. M. Rahman, Pengantar Filsafat Sosial. 2018.

[5] N. H. Nurjanah, Kajian Ontologis Studi Agama Agama. (M. T. Rahman, Ed.) Bandung: Prodi S2 Studi Agama - Agama UIN Sunan Gunung DJati Bandung, 2020.

[6] S. Zubaidi, "Antara Teodisi dan Monotesime". TSAQAFAH, 7(2) (2011), pp. 248.

[7] L. Good, Philosophy Dictionary. Jakarta: Gramedia Pustaka Utama, 2002.

[8] H. Nasution, Philosophy of Religion. Jakarta: Moon Star, 1983.

[9] Z. Jahja, Al-Ghazali's Theology: A Methodological Approach. Yogyakarta: Learning Library, 1996.

[10] D. M. Latif, The Development of Modern Theology, (DA Muslim, Ed.) Gowa: Alauddin University Press, 2020.

[11] Maftukhin. "Said Nursi's Theodic Thought on Natural Disasters: The Combination of alGhazali and al-Rumi's Thoughts". Tsaqafah, 14(2) (2018), pp. 260.
[12] N. Rouzati, (2013). The notion of Divine Trial in the Qur'an: A Critical Analysis and Reappraisal of the Bala Narratives. Doctoral Dissertation, 2013, pp. 163-174.

[13] U. Nurhayati, \& Mihajir. Contextualization of Disaster Education in Al-Ghazali's Islamic Education Perspective. International Conference on Islam and Global Issues (ICIGIs) (pp. 265267). Banten: State Islamic University Sultan Maulana Hasanuddin, 2019.

[14] I. M. Marpaung, "Nature in the View of Abu Hamid Al-Ghazali". Kalimah, 12(2) (2014), pp. 285 .

[15] E. H. Kusuma, Hubungan Antara Moral dan Agama dengan Hukum. Pendidikan Pancasila dan Kewarganegaraan, No. 2, 2015.

[16] E. D. Octavani, A. Rutam, \& Rohmatun, "Religiusitas dan Kedisiplinan Pada Anggota Polri”, Proyeksi, 6(2) (2011), pp. 58-67.

[17] F. Djamil, Filsafat Hukum Islam (Vol. cetakan 1). Jakarta: Logos Wacana Ilmu, 1997.

[18] Syarifuddin, "Hubungan Antara Hukum dengan Moral dalam Islam", Tahkim, 10(1) (2014) 